\title{
Imagen Pública: espectros estético-políticos de la imagen ${ }^{1}$
}

\section{Public Image: Aesthetic-Political Spectrums of the Image}

\author{
Juan Pablo Arancibia Carrizo \\ Universidad de Santiago de Chile \\ juan.arancibia.c@usach.cl
}

\section{Resumen}

Diversos análisis contemporáneos postulan un cambio del régimen representacional de "lo público" — destitución del lógos por medio de la irrupción de la imagen-. Ante dicho diagnóstico, sugerimos atender a la prematura existencia de un campo visual constitutivo de "lo público". Se compone allí un régimen de imágenes que expresa las condiciones de visibilidad y las gramáticas del orden cívico que diagraman el nacimiento de la ciudad y la "comunidad política". Postulamos aquí la necesidad de emprender una "arqueología visual de lo público" que advierta la densidad histórica, figurativa y performativa de una incipiente configuración de la "imagen pública" y del orden visual de "lo público".

Palabras clave: "Imagen pública", visualidad, mirada, "lo público", "óptica-política".

\section{Abstract}

Several contemporary analyses postulate a change in the representational regime over "the public sphere" - destitution of logos through the irruption of the image. Given this diagnosis, we suggest addressing the premature existence of a visual regime that is constitutive of the public field. There it is composed a regime of images that expresses the conditions of visibility and the grammars of the civic order which diagram the birth of the city and the "political community". This research report postulates the need to undertake a "visual archaeology of the public sphere" that notices the historical, figurative and performative density of an incipient configuration of the "public image" and the visual order of "the public sphere".

Keywords: "Public image", visuality, gaze, "public sphere", "political-optic".

1 El presente trabajo fue inicialmente encomendado en el marco del proyecto "Fondos Basales MECESUP USA 1799" en la Escuela de Periodismo de la Universidad de Santiago de Chile, durante 2018, bajo la dirección del investigador responsable Dr. René Jara. Posteriormente, los problemas que conciernen a la configuración de la ciudad, el espacio público y su relación con el nacimiento de la democracia y la tragedia griega, resultan objetos de la investigación en curso del proyecto Fondecyt Iniciación 11190173 "Estudio de la categoría de stásis en la tragedia y democracia griega. Hacia una genealogía trágico-política de la democracia" (2019-2021), investigador responsable Dr. Juan Pablo Arancibia Carrizo. 


\section{Introducción}

Por “imagen pública”, en la actualidad, se acostumbra a designar el modo de figuración, producción y escenificación medial de un personero político, una persona pública o incluso un personaje mediático (Gordoa). Luego, la misma noción se aplica y extiende a instituciones, gobiernos, empresas y organismos de la sociedad civil (Elizalde 37-76). En estas nominaciones se halla en común la idea de que la imagen se habría tornado pública (Tornos, Galán y otros 185-187) en cuanto ha alcanzado una importancia y una jerarquía en la mediatización de los modos de significar y representar las identidades y sentidos sociales (Verón 87-100). Esta pretendida mutación de la "logósfera" a la "grafósfera", y hasta la "videósfera", habría depuesto el ethos racional de lo público, para instaurar un régimen del pathos de la imagen, declarando la era y el imperio de lo visual (Debray 176).

Esta noción de "imperio de lo visual", hoy tan común, parece ser el resultado de un conjunto de complejas transmutaciones que definen el "giro icónico" (Moxey 98) e indican que el espacio público quedaría reducido a un "objeto estético", signado por su inmanencia significante (Baudrillard 133-137). Así, "lo público” —entendido como el canon racional de la palabra - habría sido destituido por una imagen fraudulenta y espectacular, que simula una impostura y escenificación — esta vez vaciada y espectral- de "lo público" (Amado 13-95).

Según esta lógica, la imagen parece evocar, y al mismo tiempo suplantar, "lo público" mediante una efigie que espectra y proyecta una figuración privatizadora y estetizante de la "res pública" (Sennett, El declive del hombre público 626-638). De modo que la privatización estética y espectral de la imagen implica y sentencia la destitución del régimen del "significado" y el vaciamiento de la "representación" racional de "lo público" (Habermas 172-208). Aquello que se designaba "espacio público" —así como el propio discurso público-político-, ahora se acantona en el orden de la "imagen objetual" y se consagra como "imagen-estética" "liberada" de la significación representacional "logocéntrica” (Moxey 98). Esta imagen pública y política habría degenerado ya desde finales del siglo XVII, cuando "los artistas produjeron imágenes cada vez más gratuitas y sin nexo aparente, en un alarde de virtuosismo que terminó en el vacío” (Gruzinski 150).

Acontecida esta de-sujeción y des-anclaje representacional de la imagen, esta habría alcanzado su soberanía en cuanto objeto visual estético (Jiménez 53), prescindiendo de toda exigencia referencial y normativa emanada de algún sustrato racional o una gramática argumental, como mecanismo de regulación y legitimación ético-política de lo público. Pensado así, la imagen deviene no solo la materia significante, sino el soporte histórico, técnico y simbólico del espectáculo como expresión de un modo de producción específico y de sus relaciones sociales (Debord 21-29). Allí la figuración de lo público adoptaría una singularidad antropológico-cultural cuya especificidad de lo público se define por el régimen visual de estetización, léase la espectacularización de la política (Dayan 198-201). 
Sin embargo, este proceso no se trataría solo de la estetización de la "res públicopolítica" devenida "objeto estético", sino radicalmente de una "estetización de la mirada" como un dispositivo visual regulativo y constitutivo de lo público (Virilio 23). Aquello implicaría la estetización de la experiencia - siempre imaginaria - de "lo común" y del "objeto visual de lo público" (Ossa, El ojo mecánico 29-39). Con ello, se habría estetizado el propio proceso de configuración del sujeto, o de aquellas subjetividades que se constituyen y disponen en relación con lo público (Ossandón 11-37). De modo que, en el marco de aquellas mutaciones y emergencias, lo público-político ya no se distinguiría del espectáculo, y más precisamente, el orden de "lo público" se produce y re-produce espectacularmente configurando su propio régimen de politicidad (Arancibia 65-108).

Se constituye así una "gubernamentalidad escópica" como una tecnología visual de control y clasificación de la población, escenificada y amenizada mediante los rituales del espectáculo estatal (Ossa, "La metamorfosis del príncipe" 224). Esto se explicaría, en términos de Escobar, porque la expansión tecnológica altera el sentido de la experiencia estética, apura la formación del público masivo e instaura el régimen de lo fantasmagórico moderno quebrantando las bases de la autonomía de lo estético. Si la irrupción de la mercancía supone la producción masiva y la reproductibilidad técnica del arte oblitera el aura para ofrecerla al consumo masivo (Benjamin 3-5), "la fabricación industrializada de las mercancías dota a éstas de una nueva aura: la fantasmagoría mítica de lo siempre-nuevo, el encantamiento de la moda, la seducción espectacular del artículo expuesto en vitrinas" (Escobar 37-38).

Si bien el trazado de esta breve narración describe, grosso modo, algunas articulaciones y tensiones constitutivas del cambio histórico del sensorium moderno de lo público-político, sugerimos a continuación evocar otro mosaico - en ocasiones dado al olvido-, precisamente para ilustrar que aquella emergencia histórica de "lo público" suponía y vertebraba un conjunto de nociones y principios que definían un régimen visual constitutivo de la ciudad-estado. El análisis de la sustitución modernocontemporánea del lógos racional hacia el imperio del pathos de la imagen no habría de soslayar que en el germen de "lo público" habría estado inicialmente presente un gravitante principio escópico que servía de fundamento seminal a la organización visual de la ciudad y a la composición de un diagrama óptico-político de las relaciones de poder. Este régimen geométrico-ocular implica y tangencia la embrionaria producción de una "imagen-pública" que opera como premisa y condición de posibilidad para la instauración y funcionamiento de una judicatura visual de "lo público".

\section{Hacia una arqueología visual de lo público}

En la historia de Occidente, la más temprana constitución de la noción de "lo público" se construye al amparo de una concepción y comprensión de un régimen visual que le define y sostiene. El lenguaje de la "exphrasis" (Cassin, Vocabulaire européen 
des philosophies 288) bosqueja múltiples e inabarcables fragmentos y testimonios que la literatura ofrece de alegorías, leyendas y metáforas visuales que describen la creación y organización del mundo (Hesíodo 9-59). Innúmeras imágenes dan cuenta, asimismo, de la transmutación del antiguo mundo mítico al emergente racionalismo clásico (Burckhardt 61-76).

Sin considerar la imaginería de los mitos sumerio-babilónicos (Gilgamesh Enuma Elish) y su derivación mítico-egipcia (Bernal 29-90), en lo que se reconoce como orígenes de la Literatura Occidental, ya se manifiesta la centralidad y el poderío de la visión en el hexámetro épico de Homero, donde emerge una narración sobre la base de la impresión de imágenes cuya vivacidad estremecedora se acrecienta y graba en la retina del tiempo (Murray 25-66). En efecto, la figuración de la poética Homérica - heredera de la épica micénica - evoca las instituciones sociales y políticas con cruentas imágenes del sufrimiento heroico en que los dioses y los hombres pugnan por su gloria y sus dominios (Rodríguez Adrados, Fernández-Galiano y otros 321-353). Muestra de aquello es la emblemática figura mítica del monstruo de Argos Panoptes, sirviente de Hera, centinela del Olimpo, guardián de Ío y muerto a manos de Hermes (Burkert 259-263). De igual modo, la imagen se presenta en los mitos teogónicos de Hesíodo, cuyos trazos describen la creación divina del mundo, desde aquel oscuro "Caos" (Vernant, Érase una vez 40-41), hasta el gobierno de Zeus, y la instauración de una justicia que se impone a los hombres, en cuya estructura piramidal emergen y se proclaman los derechos de un pueblo (Hesíodo 61-107).

Es mediante imágenes de la physis y del kósmos con que los físicos jónicos representan una ciencia racional naciente que explica los elementos, sus principios y leyes (Barnes 62-68); imágenes ilustran cómo los mitos órficos transmutan de una divinidad múltiple y antropomórfica hacia un "monoteísmo" en el "Testamento de Orfeo" (Bernabé 125-128). Asimismo, es mediante imágenes que los textos pitagóricos postulan una otra cosmovisión esférica, no en torno a aquella physis que se tiene “ante los ojos", sino a la relación del alma, el número y la armonía que compondrán un ordenamiento general sobre la cosmología, la música y la política (Cornavaca 67-95).

Cantando imágenes es que la poética lírica anuncia la emergencia de una subjetividad en formación, una psiké poética de la circunstancia, una incipiente estética política que figura un "punto de vista" (Ferraté 11-25); así es como el materialismo agnóstico de la sofística protagórica esboza la doctrina del "homo mensura" como relación primordial con la naturaleza (Protágoras 17-35); o la misma tragedia ática que -mediante el genio de Esquilo, Sófocles y Eurípides- eleva a su rango más conspicuo el théatron de la imagen pública de la ciudad y la política, donde resplandece la figura del héroe tras el fondo oscuro de una muerte cierta (Lesky, La tragedia griega 29-75).

Allí, se pone en juego una delicada relación entre la imagen teatral y la ciudad espejeándose a sí misma, abriendo y obturando un juego de máscaras que muestra, insinúa y oculta. La "exphrasis" trágica y la imaginería teatral aporcan el campo visual de la comunidad que se imagina a sí misma (Zeitlin 138-139). En efecto, se vertebra 
ahí una estrecha relación entre la escena del teatro y la figuración óptico-cívico-política del dispositivo asambleario, tan propio y constitutivo de la tragedia como del naciente orden democrático (Gallego, "La asamblea" 17-19). El teatro y la ciudad se miran y se piensan mutuamente, y en la poética trágica esta relación escópica se hace vívida y palmaria, coimplicándose como espectadores y ciudadanos (De Romilly 115-122).

Esta pulsión escópica se asienta en la misma configuración del discurso filosófico, en cuyo núcleo socrático, platónico, aristotélico, se fabulan nítidas imágenes de luces y sombras que distinguen la verdad y la mentira, el conocimiento y la ignorancia, la virtud y el vicio, la vida y la muerte, de modo que el ocularcentrismo de la tradición filosófica realza el "poder de la visión" (Jay 25-69). Allí, el principio de la revelación y el des-ocultamiento de la verdad hacen del enunciado filosófico - pero también del discurso cívico político - un juego remisional de diferendo y reciprocidad entre luminosidad y oscuridad, entre claridad y opacidad, en las que deambulan y se debaten los hombres que migran de la imagen religiosa hacia la imagen racional-científica del mundo (Detienne 217-227). Así se trama e intensifica una estrecha relación entre el orden escópico de las nacientes filosofía, la ciencia y las seminales disposiciones jurídicas de un derecho emergente (Gernet, Anthropologie de la Grèce Antique 227).

Asimismo, la propia historia política de Grecia se va poblando de una iconografía que simboliza sus mitos, sus conflictos, sus hazañas, sus penurias, sus héroes y gobernantes. Mediante estas imágenes los historiadores antiguos reglamentaron y estamparon la retina de la memoria política de Occidente (Finley 71-94). Así como Heródoto narra la oscura y muda ceguera que condena a los esclavos escitas (Libro Iv 1-144), Tucídides describe con desgarradoras imágenes los acontecimientos de Córcira en la cruenta guerra del Peloponeso (Libro III, 81-85). Mientras Plutarco se empeña en contrastar aquellos horrores con cierta virtud política ateniense (Pericles XxxviII-XXXIX 310311), Demóstenes intenta preservar el carácter democrático de Atenas y la Hélade, fabulando imágenes para declarar al imperio tiránico de Filipo como la febril patología política que arruinará a Grecia entera (25-31).

En todas estas diversas narrativas y tradiciones, se advierte una primigenia y persistente inteligibilidad visual o una "imaginación política" que cruza transversalmente el proceso de conformación de la ciudad, su religión, su arte, su cultura, su historia, sus actores, instituciones y su régimen de verdad. Es sobre este juego de imágenes que se ha constituido la tradición y la memoria política de Occidente, pues como indica Agamben, la memoria no es posible, en efecto, sin una imagen que espectra (phantasma), una imagen que es ella misma una afección, un pathos de la sensación o del pensamiento. Pero esa condición espectral de la imagen no remite a una entidad anulada, impotente y disuelta, antes bien, "la imagen mnémica está siempre cargada de una energía capaz de mover y turbar el cuerpo" (Agamben, Ninfas 14).

Esta imaginación política no solo se orienta y limita a regular las relaciones de convivencia y conflictividad humana, sino que alcanza una densidad y complejidad mayor, en cuanto se constituye como un principio filosófico y epistémico que explica 
las leyes generales de la naturaleza, al tiempo que produce y abastece de sentido a la existencia humana (Jaeger 150-180). De modo que existirá una muy estrecha relación entre el orden ocular de la pólis con los principios óptico-epistémicos y la axiología visual de la filosofía.

Esto se deja apreciar en la amplia y riquísima variedad del más incipiente arte griego, que testimonia esta implicancia y transmutación. Desde el arte protogeométrico arcaico al arte geométrico clásico, a través de la cerámica, las vasijas, la orfebrería, la escultura, la pictórica, la literatura, la poesía y finalmente su arquitectura, los griegos vivieron y evidenciaron la estrecha relación entre imagen, arte, vida y ciudad (Sarti 6-115).

Conocida resulta entonces la preeminencia de la visualidad como fundamento de la inteligibilidad filosófica. En los textos medios de Platón, y por cierto en los tardíos, el problema de la "representación" será central y está anclado a un principio visual del conocimiento. En Parménides, por ejemplo, Platón simula un pretendido diálogo entre el viejo Parménides, Zenón y un todavía joven Sócrates, para plantear el problema de la "Forma", la posibilidad de su inteligibilidad y los principios que le rigen para producir conocimiento de lo Uno y lo que es (130a; 135d; 166a-b). La misma aprehensión sobre la forma y las apariencias se postula en Filebo (16c-d) haciendo referencia al fuego de Parménides, como en Timeo (45a-46c), Fedón (99d-100c-d) y Fedro (265d-e, 266b) se insiste en la centralidad de la visión y en la corrección de la doctrina de las ideas para superar lo engañoso de la fantasía y la apariencia.

Este problema visual del conocimiento se desprende del propio Poema Didáctico de Parménides, en cuyo proemio Parménides viaja en el carro del sol por una carretera que le lleva a las puertas del Día y la Noche, donde una diosa — presumiblemente la ninfa Hypsipyle- le recibe para traspasar el mundo de las apariencias y prevenirle de las vías de la Verdad y de la no-Verdad: "La Luz y la Oscuridad son los dos opuestos principales de las erróneas apariencias”. En los fragmentos 6, 11, 4-9, 7, la diosa le advierte contra la vía de la Apariencia, para que no se confíe en ella, pues arrastra hacia la creencia mortal basada en la experiencia sensible:

te aparto de la Vía por la que transitan, bicéfalos, los mortales que no saben nada; pues la perplejidad guía el deambulante pensamiento en sus pechos. Son llevados ciegos y sordos, aturdidos, como hordas sin discernimiento, que han decidido creer que es y no es, lo mismo y no lo mismo, y para quienes hay una vía para todas las cosas [...] pero tú apartarás tu pensamiento de esta Vía de investigación y no dejes que la costumbre que viene de la mucha experiencia te fuerce a poner en esta Vía un ojo perdido y una lengua y oídos aturdidos, sino que juzga mediante el razonamiento la muy debatida prueba que te digo (Heidegger, Parménides fragmento 7).

Cornford extrae de este fragmento la conjunción entre la no-verdad y la vía de la apariencia, traduciendo brotôn dóxas por "lo que les parece a los mortales"; tà dokoûntal por a) "lo que parece real o aparece a los sentidos"; b) "lo que parece verdad, lo que 
todos los hombres, confundidos por los sentidos"; c) "lo que ha parecido correcto a los hombres" (Platón y Parménides 76-77).

A partir del mismo poema de Parménides, Heidegger insistirá en la tensión visual entre la Verdad (alétheia) y lo Falso (pseudos) para plantear el problema de la mirada (theáomai). "Mirar", escribe Heidegger, es en griego theáou. Sorprendentemente, solo es conocida la forma medial theáomai, traducida como "contemplar" o "presenciar"; por eso se habla de théatron, el lugar del espectáculo. Theáomai, en sentido griego, significa proveerse a sí mismo con la mirada, esto es, theá, como el sentido de la vista, en la cual algo se ofrece y se presenta a sí mismo (Heidegger, Parménides 133-135).

Esta episteme óptica implicada entre el ser y el conocer instaura un principio luminoso del "saber" y la "verdad" del que probablemente la filosofía no consiga despegarse a lo largo de su historia. Precisamente la cuestión del saber (episteme) y la verdad (alétheia, des-ocultamiento) en su relación con la forma (eidos) es lo que aparece en la mentada alegoría de la caverna en el libro vi de la República. Allí, la gruta como el espacio visible donde moran los hombres en penumbra remite a un ámbito exterior inteligible de las "Ideas" cuya claridad y prístina corrección del saber conducen al Bien (Platón, República vir 514a-541).

Hágase notar que todo el diálogo entre Sócrates y Glaucón, desde 514a hasta 518b, se centra en la dimensión visual y que las primeras interpelaciones giran en torno a la imagen e imaginación: “-imagina una especie de caverna subterránea”; "-la imagino”; "- ahora represéntate a unos hombres que permanecen encadenados"; "-los veo"; “-¿qué cosa verían estos hombres?” (Platón, República vir 514a-516). Desde luego esta alegoría ha sido exhaustiva y profusamente estudiada y comentada, haciéndose notar que la caverna sería un anticipado cinematógrafo subterráneo y rectangular en que los espectadores están sentados de espalda a la puerta y de cara a una pared; detrás de ellos hay un fuego encendido y entre ellos una mampara o telón donde se proyectan sus sombras (Platón, República viI 514. Nota de la edición del Centro de Estudios Políticos y Constitucionales).

Menos conocida resulta la clave de lectura que Heidegger ensaya sobre la misma alegoría. Este señala que el texto comporta "un giro en la determinación de la esencia de la verdad", sin embargo, advierte que aquella alegoría visual sirve de comienzo para el diálogo sobre la esencia de la pólis (La doctrina platónica de la verdad 173-198). Heidegger no descuida el hecho de que Platón ha dispuesto esta escena inicial de la alegoría cívico-ocular para luego atender a la cuestión de la educación (paideia) de los hombres que habrán de vivir en común. Desde luego que en la perspectiva platónica se funden la cuestión de la verdad, del saber y del bien, pero se imbrican desde una metáfora luminosa consustancial a la noción de alétheia. Este diagrama estará concebido desde una figuración geométrica - herencia pitagórica en Platón- que se expresa nítidamente en la teoría de las esferas que disponen el principio regulador de la armonía, desde los cuerpos celestes, la música, hasta la convivencia política de los hombres (Platón, República x 617 b-619a). 
Es necesario, entonces, servirse de los bordados que hay en el cielo como ejemplos para el estudio de los otros, en cierto modo como si se hallaran dibujos que sobresalieran por lo excelentemente trazados y bien trabajados por Dédalo o algún otro artesano o pintor, al verlos, un experto en geometría consideraría que son sin duda muy bellos en cuanto a su ejecución (Platón, República vir 529e).

Esta preeminencia geométrica y visual del saber no será menor en Aristóteles, quien en el libro viII (8-9) de la Física insiste en la circularidad del movimiento esférico de los cuerpos:

De ahí que la esfera en rotación en un sentido esté en movimiento y en otro esté en reposo. La razón de esto es que pertenecen al centro, pues el centro es como el punto de partida, el punto medio y el punto final de la magnitud [...] Y resulta esta reciprocidad: puesto que el movimiento circular es la medida de los movimientos, tiene que ser el movimiento primero" (Libro viII 9, 265b).

Más tarde, en la Metafísica, Aristóteles reitera su representación esférica proponiendo un complejo sistema de movimientos de los cuerpos celestes que diagraman 47 esferas que organizan la dinámica de todos los cuerpos y que mediante la observación se prestan a ser sabidos (Libro XII 1073b-1074b).

Precisamente en el libro i de la Metafísica, Aristóteles sostiene que todos los hombres por naturaleza desean saber, y señal de ello es el amor a las sensaciones, las que son amadas por sí mismas, y por sobre todas las demás, las sensaciones visuales: "preferimos la visión a todas las demás. La razón estriba en que ésta es, de las sensaciones, la que más nos hace conocer y muestra múltiples diferencias” (980a). Si bien existe una clara divergencia entre Platón y Aristóteles en el modo de resolver la relación con la imagen, y específicamente con el arte, en ambos filósofos la cuestión visual será un problema fundamental a resolver en su aspiración a la verdad y al conocimiento.

En Platón, la noción de "mímesis" está imbricada con la anagnórisis, de modo que el artista que se distancia de la referencia se torna un falsificador de la verdad y en consecuencia del bien. De allí que para Platón el arte posee un carácter moral y la creación de imágenes desprendidas de la verdad se torna nociva: "Dejamos establecido, por lo tanto, que todos los poetas, comenzando por Homero, son imitadores de imágenes de la excelencia y de las otras cosas que crean, sin tener acceso nunca a la verdad" (República x 600 e-601a); "Por lo tanto, es justo que lo ataquemos y que lo pongamos como correlato del pintor; pues se le asemeja en que produce cosas inferiores en relación con la verdad, y también se le parece en cuanto trata con la parte inferior del alma y no con la mejor" (República x 605a-b).

Para Platón el mundo de la apariencia condena al arte al engaño y falsedad, pues el único camino al bien es el conocimiento y la verdad. De allí que el mundo de las imágenes debe ser superado por la doctrina de las ideas y debe prescindir del arte de las apariencias porque: a) los poetas componen bajo inspiración y no usando la razón; 
b) construyen imágenes falsas y en consecuencia enseñan ideas falsas; c) la imagen mimética degrada ontológicamente la realidad; y e) la imagen manipula las pasiones de los espectadores (Aspe 121).

En Aristóteles, en cambio, el arte es producción creadora de formas nuevas y por tanto creador de un conocimiento nuevo. Si para Platón la poesía es inspiración, para Aristóteles es tekné que puede ser aprendida y enseñada; si para Platón la apariencia y la imagen es falsedad, para Aristóteles la imagen es una nueva forma creada, y por tanto resulta un ser verdadero; si para Platón el arte manipula las emociones, para Aristóteles las libera y purifica (Aspe 122). De allí que Aristóteles conciba y valore a la tragedia como imitación de una acción esforzada y completa, que produce la katharsis como temor, compasión, purgación y purificación (Poética 1.449b-15-32).

\section{Emergencia de la ciudad y la imagen "público-política"}

Tras las consecutivas migraciones de las distintas estirpes griegas - que remiten al tercer y segundo milenio antes de nuestra era-, una vez asentado el mundo de la Hélade, y tras el desmoronamiento de la Grecia Micénica y el acabamiento del "periodo oscuro", en el contexto de transición de la Grecia Arcaica a la Grecia Clásica - entre el siglo viII y vi a. C. - , se instaura la experiencia política de la ciudad (Wilcken 71-90). Esta emergencia es coligada e impulsada por el proceso de racionalización que concierne tanto a la configuración de la ciencia física jónica (Barnes 9-25) como a la posterior e intrincada consolidación del discurso filosófico (Cornford, Platón y Parménides 19-25).

Consabido es el extenso e intrincado proceso de secularización y transmutación del mito al lógos (Bermejo 21-43). En ese marco, la configuración de la pólis y su consustancial definición de "lo público" estarían severamente comprometidas con una concepción visual de la physis derivada del imaginario de la física jónica. Se trata de una visualidad inicialmente impregnada del imaginario mítico del kósmos, que opera como principio ordenador y de figuración de la emergencia de la ciudad-estado (Vernant, Los orígenes 115-121).

Este régimen visual -que homologaba el ordenamiento de los cuerpos celestes en el kósmos con el ordenamiento de la comunidad humana-concernía principalmente a la composición y diseño cívico-espacial de la ciudad (Forrest 16-34), así como a la figuración e inscripción del cuerpo del ciudadano en la pólis (Sennett, Carne y piedra 37-72). Así, la primera diagramación de la ciudad guardaba una relación interna con la cosmogonía mítica que sostenía y explicaba la mundanidad.

Vidal-Naquet rastrea en la Ilíada y la Odisea para explicar la íntima articulación que habría entre mito y ciudad, haciendo notar la coimplicancia y convivencia entre los dioses y los mortales. Este reparto, siempre bélico y litigioso, haría de la ciudad el territorio o, más precisamente, la escenografía de la relación cívico-política entre los 
dioses y los hombres. Asimismo, establece una delicada conjunción entre la narración mítica sobre las disputas de los dioses, sus poderíos y distritos, con las propias concepciones contrariadas de los físicos de Jonia y los primeros filósofos. Así se explica que Homero hubiese adaptado la imagen jurídica de la ciudad naciente a su propia narración mítica, fundiendo mito y ciudad como una composición cosmogónica (Vidal-Naquet, El mundo de Homero 55-60). Aunque en la poética épica se escenifica a la ciudad todavía situada como laós, se la describe como espacio de expresión de los conflictos, anunciando aquella agonística disposición posterior de la pólis democrática (Plácido 22).

Vidal-Naquet se detiene en un fragmento del canto xv de la Ilíada que narra el conato entre Poseidón y Zeus por la delimitación de sus poderes. Allí resalta tres imágenes o principios que luego serán centrales y consustanciales a la organización cívico-política de la ciudad: primero, echar suertes para designar funciones; segundo, el dominio "en común"; y tercero, la jerarquía que distingue a quien ejerce el mando de quienes son los gobernados. "La Ilíada es inconcebible sin cierta presencia de la ciudad. Así, la ciudad de los dioses nos permite conocer cómo se había desarrollado la ciudad de los hombres en la época arcaica" (El mundo de Homero 59).

Podríamos decir, de acuerdo a Cornford, que los procesos de racionalización que organiza la experiencia común y las primeras ciudades griegas fueron concebidos y heredados del mito (Principium Sapientiae 193-240). Más precisamente, como sugiere Loraux, las primeras ciudades fueron concebidas a "imagen y semejanza" del mito, en cuanto ellas mismas comportan imágenes que representaban míticamente al kósmos. Ha sido precisamente Nicole Loraux quien, acudiendo a cierta imaginación profana, se ha atrevido a imaginar bellamente un recorrido por aquel espacio visual de la pólis griega del siglo v.

Los mitos están presentes en todas partes: manifiestan el espacio de la ciudad, donde dibujan los recorridos, donde forman las constelaciones, complejos nudos de tensiones y de relaciones [...] Imaginemos un instante lo que un ateniense del siglo v o del Iv hubiera visto o evocado al seguir este recorrido [...] En el Ágora, centro de la vida política, dominada al sudeste por la Acrópolis, al sur por la colina del Areópago donde Atenea un día reunió el primer tribunal, al noroeste por el templo de Hefesto, los doce dioses olímpicos se aproximan a los héroes atenienses: para ir más rápido, no se mencionará más que los diez Epónimos, cuyo monumento juega un papel esencial en la vida política y militar de la ciudad, y Teseo, cuyas hazañas son contadas en el friso interior del Hefesteion y en las pinturas de la Stoa poikilê [...] A cada paso se levantan figuras heroicas, en cada lugar se inscriben relatos míticos [...] Detendremos aquí la enumeración; en el campo como en la ciudad, los mitos le hablan a los ciudadanos de la ciudad (Mito y política en Atenas 57-58). 
Habría entonces una correspondencia y contigüidad entre la imagen mítica del kósmos y la figuración visual de la pólis. Aquella visualidad mítica será traspasada al proceso de secularización, como a la propia constitución del discurso filosófico y político. Así, la ciudad va adoptando una geometría visual y un canon racional escópico, autónomo, que configura los principios y fundamentos del nacimiento de la política, es decir, aquella experiencia de figuración, representación e institucionalización consciente de la sociedad (Castoriadis 68-69).

De esta manera, podemos sostener que la organización visual de la ciudad era el modo performativo no de "representar", sino de constituir y modelizar las relaciones sociales entre los agentes activos de la comunidad política. Su composición, su diagrama y su dinámica expresan una compleja organización destinada a preservar y posibilitar "lo común", ante un cuadro histórico de endémicos enfrentamientos de clases que disputan por la figuración y reconocimiento de su visión de mundo (Glotz 373-383).

Así, la ciudad devenida imagen - y la imagen devenida ciudad - no concierne a una representación, antes bien, a la encarnación, pues como indica Bonnefoy, "llamamos imagen a esa impresión de realidad al fin plenamente encarnada que paradójicamente nos viene de palabras apartadas de la encarnación. Imágenes, mundos-imágenes” (Bonnefoy 28). En ese sentido, la ciudad conserva un aspecto decisivo del mito y la tragedia en cuanto comporta una imagen vívida y palmaria que activa y despliega un régimen histórico de saber y de verdad (Vidal-Naquet, El espejo roto 40-44). Por ello, el mito entabla una relación íntima, pero también delicada e intrincada, con el rito, toda vez que aquella imbricación visual y espacial comporta y expresa un régimen de orden cívico y de instituciones sociales que producen y definen la interacción social de la comunidad (Burkert 66-67; Kirk 181-185).

Podríamos sostener entonces que la ciudad se constituye a partir de cierto juego de imágenes, pero se trataría de una imagen kolosal en cuanto ella no re-presenta pasivamente, sino que presentifica, materializa y pone en ejercicio cierto conjunto de imágenes vitales de la ciudad, es decir, se trata de una imagen-experiencia, de una imagen-acción, de un "doble" que porta y comporta ciertos ritos cívico-políticos constitutivos de la comunidad (Vernant, Mito y pensamiento 302-307). Si la ciudad se concibe a partir de la imagen kolosal, en cuanto ella deriva del kolossós, no es una imagen pasiva, quieta e inmóvil que reproduce un referente, sino que es una imagen en cuanto realiza la encarnación de un "doble" que apertura, invoca y provoca una relación incómoda, inquietante y ominosa. Trátase de una imagen que incita la relación con lo Otro (Bozal 65-71).

La ciudad como "imagen-kolosal" abre, suscita y pone en relación con una diferencia y extrañeza litigiosa de la comunidad, pero que al mismo tiempo pertenece y concierne a la propia comunidad. La imagen kolosal de la ciudad entonces no viene a pacificar ni a domeñar, sino que es el advenimiento de lo kolosal que invoca e interpela a la diferencia agonística, constituyente y adversarial de la comunidad. Se trata de imágenes vivas, puestas en práctica y en ejercicio, una imagen activa y colectiva que 
presentifica acciones específicas de la pólis, aquello que Gallego ha denominado como el dispositivo asambleario de la pólis, que concierne al imaginario adversativo y a la prefiguración polémica y conflictual de las leyes y lo común en la ciudad democrática (Gallego, La democracia en tiempos de tragedia 163-165).

En toda imagen, por la praxis en que está inserta, pugnan energías colectivas antagónicas; en cada imagen, por el lugar concreto que ocupa en una contingencia y en un contexto determinado, se señalan los triunfos, los chantajes, las adulteraciones, las derrotas, los conatos, las extorsiones de las fuerzas que están en lucha. Detrás de cada imagen está la huella todavía fresca de la exclusión de otras y la inminencia de ser suplantadas por nuevas (Kay 37).

De este modo, la geometría kolosal de la pólis no se orienta hacia la cancelación y obliteración del conflicto y la diferencia de la comunidad, sino que la organización, composición y distribución espacial de los cuerpos y el poder en la ciudad obedecen a una figuración óptico-política destinada a preservar y posibilitar el reconocimiento equivalencial de la diferencia en la vida en-común. De allí que, hacia el siglo vint, la ciudad se transforma sustantivamente respecto de las monarquías y palacios micénicos, produciéndose el advenimiento de la ciudad-Estado, o de la pólis, como escenografía fundacional de lo público-político. Como explica Vernant, el espacio urbano no gravita más en torno de una ciudadela real que lo domina; ahora se centra en el "Ágora", que es por excelencia el lugar donde circula libremente la palabra entre iguales.

El milagro griego: un grupo humano se propone despersonalizar el poder soberano, ponerlo en una situación tal que nadie pueda ejercerlo solo, a su antojo. Y para que no sea posible apropiarse del poder, se lo "sitúa en el centro". ¿Por qué? Porque, para una comunidad de individuos donde todos, como ciudadanos de una misma ciudad, se consideran "semejantes", "iguales" en el plano político, el centro representa, a equidistancia de cada uno, un espacio común a todos, no apropiable, público, abierto a los ojos de todos, socialmente controlado, donde la opinión de cualquiera, libremente expresada mediante la palabra en el curso de un debate general, es puesta a disposición de todos" (Vernant, Atravesar fronteras 135).

Así, el gran acontecimiento de emergencia de la pólis griega tangencia una composición y diagramación física de una racionalidad óptico-política destinada a procurar los principios de isegoría e isonomía de la pólis democrática. En ese sentido, como afirma Castoriadis, se puede señalar que los griegos, al inventar la pólis, ciertamente inventan la política en su sentido más pleno (69).

Sin embargo, destaquemos que la invención de la pólis y de la política en el siglo vIII a. C. es, sobre todo, un acto de "imaginación política", un modo de figurar, componer, diagramar, concebir y reconocer las relaciones de espacio y poder que gobiernan los cuerpos. En ese sentido, siguiendo a Didi-Huberman, podemos reconocer una 
coimplicancia primordial entre política e imagen en cuanto esta imaginación política concierne a la facultad de "aparecer" de lo político como tal, pues lo político allí concierne a la posibilidad misma de la "aparición" como aquella potencia expositiva y figural de la comunidad. Así pues, la configuración de la ciudad y de "lo público" es un artefacto visual, dicho en términos de Didi-Huberman: un "montaje" (García, "La comunidad en montaje" 96-117).

La ciudad "montaje" es una composición visual de las relaciones de poder que le constituyen. Si bien en el contexto transitivo de la Grecia arcaica a la Grecia clásica se consignan tempranos y significativos cambios en la nueva racionalidad jurídica, que van desde Dracón, Solón, incluso a Pisistrato (Cohen 25-44), será con las reformas clisténicas que la ciudad adopte una decisiva configuración propiamente público-política (Mossé 25-29), pues las reformas de Clístenes se sitúan en el plano fundacional de lo político y de las instituciones democráticas (Gil Fernández 35-49). Se instaura entonces una correspondencia orgánico-institucional de la ciudad con una figuración óptica del orden, en cuyo centro geométrico y visual ("es mesón") se sostiene el delicado equilibrio simétrico de las conflictivas relaciones de las diez tribus territorialmente organizadas que componen la pólis (Francotte 28-38). Por ello, "más que de una transformación, es preciso hablar incluso, a este respecto, de una instauración de lo político, del advenimiento del plano político, en sentido propio, en la existencia social de los griegos" (Vernant, Mito y pensamiento 219).

Tal como indica Vernant, se capta aquí un giro en la historia de las sociedades antiguas. Por la constitución clisténica, la ciudad se hace democrática. El principio de la isonomía adopta un valor y relevancia decisivos para el asentamiento y estabilidad del orden público-político. Todo el nuevo ordenamiento jurídico-político que define la emergencia de la pólis se asienta en un carácter geométrico equivalencial. La ciudad-estado se organiza como un espacio político homogéneo, cuyo centro posee un valor privilegiado en cuanto eje articulador y moderador, donde todas las posiciones diversas que ocupan los ciudadanos aparecen simétricas y reversibles (Vernant, Mito $y$ pensamiento 221). Este diagrama geométrico de la ciudad obedece a un principio de representación y composición visual del orden destinado a preservar la equivalencia e igualdad entre los miembros de la comunidad.

La ubicación del Partenón en la ciudad simbolizaba su valor cívico colectivo. Visible desde muchos lugares de la ciudad, desde los distritos nuevos o en expansión al igual que desde los barrios viejos, la imagen de la unidad resplandecía bajo el sol. M.I. Finley ha denominado acertadamente su autoexhibición, su capacidad de atraer las miradas, "exteriorización". Así dice: "Al respecto nada puede resultar más engañoso que nuestra impresión usual: vemos ruinas, contemplamos su interior, caminamos por el interior del Partenón... Lo que los griegos veían era físicamente muy diferente" [...] A este respecto, el templo aporta una clave respecto a la forma urbana ateniense más general. El volumen urbano procedía del juego de superficies (Sennett, Carne y piedra 41-42). 
Podríamos decir, siguiendo a Arendt, que el principio escópico y geométrico de la ciudad es la materialización y formalización del principio de igualdad, y mediante esa imagen simétrica se garantiza y preserva la posición y condición de los diferentes. De este modo, la esfera pública implicaba una imaginación política y una composición visual de las diferencias, regimentada por un cierto principio luminoso de la ciudad: la palabra "público" significa que todo lo que aparece en público puede verlo y oírlo todo el mundo y tiene la más amplia publicidad posible [...] Sin embargo, hay muchas cosas que no pueden soportar la implacable, brillante luz de la constante presencia de otros en la escena pública; allí, únicamente se tolera lo que es considerado apropiado, digno de verse u oírse (60-61).

\section{Imagen pública y escena kolosal de la pólis}

Si la ciudad nos pone en relación con lo Otro y nos constituye como otros y otras dentro de lo común, aquello seña un principio fundacional de lo cívico-político. Y más tarde este régimen visual se cristaliza en una judicatura óptico-política que regula la ciudad como un orden compositivo de los cuerpos, sus movimientos, flujos, relaciones, intercambios y conflictos. Carl Schmitt se detiene precisamente en la noción griega arcaica de nomos para destacar en ella la dimensión visual y espacial que funda y delimita un territorio como el asentamiento de la comunidad política. El nomos que constituye a la pólis es siempre una composición visual del espacio, la estructura espacial de un orden fundado y legitimado (48-53). Así, la propia judicatura de la ciudad va adoptando una configuración visual y simbólica donde lo público-político concierne y se compromete sustantivamente con la imagen, o podría decirse, se suscita una composición ocular del poder. En ello, la imagen adoptará históricamente un carácter jurídico y figurativo que traza y delinea las fronteras iconográficas de lo lícito y lo ilícito, de modo que la imagen se mimetiza en semejanza al derecho, constituyendo una legitimidad visual del orden y la ley (Didi-Huberman, Ante el tiempo 110-115).

Esta judicatura óptico-política exige y realza la importancia de una visión común, trátase de una homónoia (conocimiento común) y de una homología (equivalencia del discurso), pues la distribución equivalente y reversible de los cuerpos que supone la isonomía y la isegoría, plasmada en la geometría ocular de la ciudad, dependen estrechamente de la posibilidad de un conocimiento común o, más precisamente, de una "visión común", de una "puesta en escena" que posibilite un hablar equivalente, un discurso, aunque diferenciado y litigioso, que sea concebido bajo condiciones de una imagen de igualdad.

La práctica del elogio y la interpretación del mito de Protágoras prueban que la ciudad es en primer lugar y ante todo una "performance". La homónoia se obtiene por medio del logos, y también; la homónoia, acuerdo de las mentes, es una homología, acuerdo acerca de las palabras. El consenso sofístico resulta, 
así, un consenso sometido a tensión, un consenso vibratorio en el que las diferencias, y sin duda también el diferendo, son arrastradas en el movimiento y llevadas por él: lo que hay que seducir en todo Perí homónoias es, a decir verdad, la stasis misma (Cassin 157).

De esta manera, la ciudad es configurada como una "puesta en escena" donde concurren las múltiples fuerzas a la disputa por su re-presentación, inscripción y reconocimiento. En ese sentido, la escenografía de "lo público" articularía una relación entre aquella concepción esférica, concéntrica, luminosa, equivalente y recíproca -isegórica e isonómica-, adoptando la forma de la escena teatral; un plató cívico político que haría posible ver y ser visto, hablar y ser escuchado. De modo que la propia ciudad se torna un escenario que configura y diagrama un "campo visual" de lo públicopolítico. Aquel régimen de visibilidad que Ossa denomina realismo fundacional como un espacio icónico que inaugura un modo de organización visual del mundo (Ossa, "El soberano óptico" 220).

Trátase de una economía política de la mirada, en cuanto lógica de producción y circulación de lo visible, donde no se trata de que "todo" sea visto o escuchado, sino solo aquello que la propia retícula de inclusión y exclusión del campo visual de la ciudad prefigura y reconfigura políticamente en relación con su propio juego de afecciones, litigio y confrontación. Pues allí, en lo público-político, la mirada no es simplemente ver, ni tampoco observar con mayor o menor "competencia", sino que: "una mirada supone la 'implicación', el ser-afectado que se reconoce, en esa misma implicación, como sujeto" (Didi-Huberman, "La emoción” 41).

Por ello, hacíamos notar que, en la formación clásica, se constituye una íntima relación entre ciudad y teatro, entre política y visualidad, pues la propia ciudad se vuelve el théatron donde concurren y se visibilizan los agentes, sus acciones y disputas. Aquella forma concéntrica de la ciudad-kósmos adopta la doble figura de la skené como espacio físico y simbólico. Precisamente este orden visual permite observar la coincidente emergencia contextual entre ciudad, política, democracia y tragedia, donde la figuración ocular trama una compleja nervadura entre lo visible y lo invisible, lo presente y lo ausente, como principio regulador de la valía, jerarquía y significación de los agentes que integran y organizan lo-común (Herreras 27-53). Así, la representación teatral hace de las relaciones de conflicto una escenificación pública, tornándose el teatro una escena, un "montaje" con clara significación política (Gallego, "El héroe trágico" 137-138).

Recordemos que la noción de "escena" proviene del griego skené, que era un dispositivo o artefacto montado en el plató para regular o controlar los tiempos y espacios visuales de la representación teatral. Así, la skené, por un lado, hospeda a los actores para el cambio de atuendos, pero, por otro lado, al mismo tiempo representa el espacio visual en que se desarrolla la acción (Iriarte 25). De esta manera, la skené supone desde muy temprano un campo visual expuesto y constituido por la mirada, al tiempo que 
implica un espacio de oclusión o clausura, inasequible a la mirada. Para que la verdad escénica fuese posible, era preciso que no todo fuese visto, sino que era preciso dejar de ver lo que los espectadores suponían que ocurría tras bambalinas, como condición de que luego, a la vista, las acciones y sus agentes se hicieran totalmente visibles. Así, en esa relación fronteriza y colindante entre lo visible y lo que no, se traza un orden visual narrativo, de modo que lo visto solo funciona en relación y a condición de lo no visto (Iriarte 25). Esto se evidencia en diversas obras, episodios y escenas, por ejemplo, en Las coéforas de Esquilo, cuando las puertas del palacio de Agamenón se abren para mostrar los cuerpos de Egisto y Clitemnestra tras el acto criminal de Orestes, que los espectadores no han presenciado directamente (Esquilo 930-975).

Este juego de visibilidad e invisibilidad opera también en el cambio de roles que ejercen los actores, pues en cada obra debían representar a más de un personaje, de modo que se travestían y desdoblaban en distintos roles. Esta ubicuidad figural se veía particularmente potenciada con el dispositivo de la máscara. Esta tapaba por completo el rostro y la cabeza del actor, ya que incluía una peluca. Dos agujeros para los ojos y uno para la boca entreabierta eran todos los rasgos expresivos, pero al mismo tiempo destinados a ocultar la identidad del actor. Más allá de su carácter puramente funcional, la eficacia simbólica de la máscara es clave para el cumplimiento de la función teatral, de esa tensión entre lo real y lo ficticio (Iriarte 26-27). Allí la máscara sintetiza en sí misma este juego de la imagen y la escena kolosal que comunica con lo Otro, pues al mismo tiempo que exhibe, encubre, en ese juego hace comparecer y co-aparecer la potencia y la presencia agonística del dios o del daimon cuya figura emblemática se puede expresar en Dionisos (Eurípides 1-65).

Esta propia figuración teatral se aprecia en la conformación de "lo público" que, en cuanto puesta en escena, consagra y condensa una noción de lo visual, al tiempo que comporta un trazado de invisibilidad, específicamente en aquello que más tarde se conceptúa como "lo privado". Si la oikía precisamente carece de figuración, está constreñido a un orden de visibilidad oscura, ausente, silenciada y que opera por negatividad, cancelación o falta:

Vivir una vida privada por completo significa por encima de todo estar privado de cosas esenciales a una verdadera vida humana [...] El hombre privado no aparece y, por lo tanto, es como si no existiera. Cualquier cosa que realiza carece de significado y consecuencia para los otros (Arendt 67).

De allí que podamos señalar que en la pólis no existía la imagen privada, pues, decir "imagen pública", en ese contexto, es decir dos veces lo mismo. "Lo público" es lo que sale a la luz, lo visible, lo que se deja ver, lo que implica, mientras que la oikía se registra en una visualidad ciega y muda, de ausencia, distancia y negación: lo que no figura, lo que no cuenta. Privado era privado de lenguaje, privado de imagen, privado de reconocimiento (Aristóteles, Política I 1252b-1260b). Mientras que la cuestión de la isegoría, de la isonomía y de la parrhesía implica y comporta la idea de un recono- 
cimiento, de una figuración, de una visibilidad activa, incluso, de un ascendiente o prominencia figural (Foucault, El gobierno de sí y de los otros 57-89).

De modo que, si bien la experiencia griega de la ciudad y la política conciernen al orden del discurso, del lógos, de la palabra y la declamación, este régimen discursivo es siempre un régimen escópico, donde lo especular y espectacular están sinuosamente fundidos, al rango que "visibilidad", "decibilidad" y "audibilidad" traman una relación consustancial en el dispositivo discursivo de la pólis que produce su propio "símbolo" de verdad y de poder (Foucault, Lecciones sobre la voluntad de saber 255-283).

El "símbolon", que estaba ligado a prácticas religiosas, al ejercicio del poder, pero que se mantuvo en la nueva organización política y social de la ciudad —donde se conserva, pero en otro registro, las mismas funciones de autentificación-, presta aquí su forma al ajuste de dos procedimientos de fecha, origen y estatus diferentes, cada uno de los cuales queda así autentificado por el otro [...] Al mirar hacia el pasado, la justicia según las leyes ve lo mismo que la mirada de los dioses que dominan el futuro. El mecanismo del "símbolon" que actúa a lo largo de la tragedia muestra a las claras que el tiempo de los hombres es también el de los dioses: "El tiempo que ve todas las cosas" (Foucault, Lecciones sobre la voluntad de saber 280 ).

Esta visualidad constitutiva de lo público-político implica y rezuma la propia dimensión estética de la política. Desde esta perspectiva, entonces, decir "imagen” y decir "lo público" sería una iteración. "Imagen pública”, en el contexto que examinamos, implica decir dos veces lo mismo, pues "lo público" no podía estar sino concebido como un principio de figuración y reconocimiento, así como la imagen suponía un espacio social de registro, un decorado de inscripción que la hiciera posible. De este modo, la emergencia de la pólis y la figuración de "lo público" supone la constitución de un principio ocular, un ordenamiento visual que la diagrama como una composición cívico-visual. De cierto modo, podríamos señalar que la ciudad y sus debidas funciones y dimensiones de lo público son diseñadas a partir de una inteligibilidad ocular, un dispositivo óptico-político de figuración y organización de los cuerpos.

La política sobreviene cuando aquellos que no tienen tiempo se toman ese tiempo necesario para erigirse en habitantes de un espacio común y para demostrar que su boca emite perfectamente un lenguaje que habla de cosas comunes y no solamente un grito que denota sufrimiento. Esta distribución y esta redistribución de lugares e identidades, esta partición y esta repartición de espacios y de tiempos, de lo visible y de lo invisible, del ruido y del lenguaje constituyen eso que llamo la división de lo sensible. La política consiste en reconfigurar la división de lo sensible [...] Este proceso de creación de disensos constituye una estética de la política (Rancière 18-19). 
Esta dimensión figural de la imaginación política — que está a la base de la experiencia fundacional de la ciudad, de lo público y lo político, como la instauración, diagramación y composición de un orden geométrico y agonístico- es al mismo tiempo la condición de posibilidad para la escenificación y advenimiento de lo Otro. Esta disrupción o advenimiento de lo Otro será la potencia constitutiva, pero al mismo tiempo, la emergencia del mayor riesgo de la comunidad. Esta otredad consustancial a la experiencia de lo-común adoptará una inquietante figuración de lo íntimo y lo extraño, de lo propio y lo foráneo, de lo familiar y de lo inhóspito.

\section{Imágenes (en) conflicto: la política, la ciudad, la muerte}

La geometría kolosal de la ciudad en su relación agonística y constitutiva con lo Otro se ha expresado en múltiples imágenes en la tradición clásica. En lo inmediato, y brevemente, mencionamos tres. Primero, el escudo de Aquiles. Homero, en el canto XVIII de la Ilíada, se detiene en una bella descripción-narración de una compleja mundanidad contenida y grabada, en el escudo de Aquiles. Tras la muerte de Patroclo, el héroe no solo ha perdido a su amado amigo, sino también a sus armas. La diosa Tetis, madre de Aquiles, acude al dios Hefesto para que fabrique nuevas armas al guerrero (Homero, XVIII 190-240). En el escudo se graban un conjunto de imágenes que constituyen una diégesis de la vida y del mundo, un cuadro que refiere a las distintas escenas, tiempos y espacios que constituyen la vida en común.

En otro lugar reprodujo de efímeros hombres dos urbes hermosas. Bodas y banquetes había en una de ellas, y desde sus aposentos a las novias bajo antorchas llevaban por la ciudad, y se oían muchos himeneos. Jóvenes danzarines daban volteretas, $y$ entre ellos flautas y forminges acompañaban el canto; $y$ las mujeres en pie a la entrada de sus casas se quedaban mirando. Estaban reunidos los hombres en junta, pues había surgido una disputa, y pleiteaban dos hombres por la indemnización de un homicidio. Uno afirmaba que entera la había pagado y al pueblo lo declaraba; mas el otro negaba algo haber recibido. Y zanjar el pleito querían los dos con un árbitro. En defensa de uno u otro bando gritaban las gentes; y a la multitud contenían los heraldos (Homero, XVIII 490-505).

Como ya hemos señalado, existiría algún grado de contigüidad o herencia alegórica entre el mito y la emergencia de la ciudad. Precisamente esta imbricación simbólica se deja apreciar con relativa nitidez en el relato mítico de la épica homérica. Si bien se han ensayado múltiples y eruditas interpretaciones y exégesis de la descripción homérica del escudo de Aquiles (Rodríguez Adrados, Fernández-Galiano y otros 78-82; Gil, El individuo 390; Bowra, La aventura griega 58; Lesky, Historia de la literatura griega 48; Bowra, Historia de la literatura griega 58; Jaeger 61; Gernet, Droit et institutions 64-69), en lo particular nos importa realzar de esta imagen dos aspectos 
decisivos para la fundación política de la ciudad: la presencia de una noción de lo Otro y la idea de un antagonismo consustancial a la comunidad.

Precisamente el escudo de Aquiles es la imagen que Loraux ha referido para ilustrar su concepción de la "ciudad dividida”. Allí el carácter bélico y polémico de la política se alterna con el tiempo de la fiesta y algarabía de la familia. Dos tiempos, dos escenas, dos imágenes contrariadas de lo mismo, expresando el ethos agonístico de la vida común (Loraux, La ciudad dividida 16-21). Esta imagen expresa y comporta el juego riesgoso, inestable y siempre reversible de lo mismo y lo otro, allí donde lo íntimo y apacible se torna extrañeza inclemente. Esta imagen homérica de lo familiar y lo inhóspito es lo que Simone Weil denominó “el poema de la fuerza”, refiriéndose a la potencia incierta y devastadora de lo común, como lo que reúne y cobija, pero también como lo que divide y destruye (Weil 15-43); potencia a la que Loraux identifica bajo la riesgosa figura de la stásis como "la tragedia de Atenas" (Loraux, La guerra civil en Atenas 51-83). En esta imagen homérica de la ciudad dividida se graba ostensible la cuestión agonística y el problema de lo Otro.

Una segunda imagen: la diosa Artemisa. Artemisa, hija de Zeus y Leto, es la diosa de la caza, pero también representa la virginidad eterna. Su origen ha sido discutido, algunos eruditos dicen que es propiamente griega, otros señalan que es extranjera. Algunos la vinculan a la diosa asiática Pótnia thêrôn como señala Homero: "Mucho lo reprendió su hermana, 'Señora de fieras', la agreste Ártemis” (xxi 470).

Si bien Artemisa es diosa de la caza, también cumple un rol en la conducción de la guerra. Artemisa no combate, pero sí guía y salva. Se la invoca como salvadora en las situaciones críticas, cuando peligra la supervivencia de una ciudad amenazada por la destrucción. "Artemisa interviene en el enfrentamiento cuando el empleo excesivo de la violencia rompe los marcos civilizados, en cuyo interior rigen las normas de la lucha militar, y la impulsan brutalmente al salvajismo" (Vernant, La muerte en los ojos 29-30).

A partir de que la Artemisa extranjera (escita) se vuelve griega, su alteridad se transforma, su función se invierte. Ya no expresa, como en Escitia, la imposibilidad de codearse con lo civilizado, propia del salvaje, sino, por el contrario, la capacidad de integrar en su seno lo que le es foráneo, de asimilar al otro sin caer en el salvajismo, lo que es propio de la cultura [...] El Otro como componente del Mismo, como condición de la propia identidad [...] Artemisa aparece al mismo tiempo como diosa fundadora de la ciudad, que instituye para aquellos que al principio eran diferentes, opuestos o incluso enemigos, una vida común en el marco de un grupo unido de seres idénticos entre sí (Vernant, La muerte en los ojos 35-36).

Artemisa, hermana gemela de Apolo, reúne la contrariedad de lo salvaje y la ciudad, el amor y el desprecio, la suavidad y la crueldad, diosa de la caza, pero también de la fertilidad y custodia de las bestias. Artemisa pidió a Zeus que le concediera ser doncella eterna, escoltada por numerosas ninfas venidas del océano profundo, y a Hefesto pidió que le fabricara el más noble y bello arco y flechas dignas de una diosa 
(Andrade y Vial 105-110). Artemisa que convierte a Acteón en ciervo y ordena a sus perros de caza que lo devoren; Artemisa que junto a sus ninfas cubre su rostro con máscaras de barro en el arte de la caza, pero también para burlar a su persecutor Alfeo (Graves 122); Artemisa a quien los efebos áticos al comenzar su servicio militar dedicaban una procesión de caza; a quien antes de partir a la guerra, los ejércitos ofrecían sacrificios de animales para emular el baño de sangre que impondrían a sus enemigos, así los sacrificios a Artemisa daban comienzo a la acción sangrienta de la guerra como la matanza de los hombres (Burkert 114-115).

Sin embargo, será la propia Artemisa quien custodia que los hombres en liza, caídos a la embriaguez de lo salvaje, no se despedacen y destruyan la ciudad como el modo más propiamente humano de convivencia: la política. Por ello, "la ciudad griega que hizo suya esta Artemisa extranjera, expresión de la alteridad, constituyó su 'mismo' a partir del Otro y con el Otro" (Vernant, La muerte en los ojos 37).

Tercera imagen, el rostro de la Gorgona. Trátase del Otro absoluto: ya no al ser humano distinto del griego, sino aquello que se manifiesta radicalmente distinto del ser humano: no el hombre otro, sino lo Otro del hombre. En el rostro monstruoso de la Gorgona yace la potencia sagrada que también opera a través de la máscara, "aquello que no puede tener otra forma que la máscara y que sólo puede presentarse ocultándose en toda su integridad como máscara: la faz aterradora de Gorgo" (Vernant, La muerte en los ojos 39).

A la Gorgona se la representa con el rostro más horripilante, que es un no-rostro, alada y cuya cabeza cubierta de serpientes no puede ser vista pues sentencia la muerte (Esquilo 45-55). La Gorgona no tiene rostro, lo que los griegos llamaban prósôpon, que significa etimológicamente "lo que está ante los ojos, lo que se hace ver". "La cara prohibida, imposible de mirar porque provoca la muerte, es para los griegos, una no-cara, y como tal, nunca es designada como "prósôpon"' (Agamben, Lo que queda de Auschwitz 54).

Desde el principio y por sí misma Gorgo produce espanto porque aparece en el campo de batalla como un prodigio (téras), un monstruo (pélor), en forma de cabeza (kephalé), terrible y aterradora (de ver y de oír) (deiné te smerdné te), con una cara de ojos terribles (blosurópis) que lanza una mirada de espanto (deinòn derkomené). Según La Ilíada, la máscara y el ojo de la Gorgona operan en un contexto definido; forman parte de los pertrechos, los gestos e incluso la expresión del guerrero (hombre o dios) poseído por el ménos, la furia bélica; concentran de alguna manera el poder mortífero que irradia el combatiente armado, dispuesto a mostrar en la lid el vigor extraordinario, la fortaleza (alké) que posee (Vernant, La muerte en los ojos 55-56).

La Gorgona engendrada por Gea en la batalla de los hijos de la tierra, los gigantes contra los dioses (Eurípides, Ión 985-995); muerta y desollada por Atenea, quien luego se vistió con su pellejo para lanzarse a la lucha contra los gigantes, representa la potencia 
ominosa de lo otro, aquella potencia que precisamente proyecta ese juego reversible entre lo visible y lo invisible, lo representable y lo irrepresentable, esa ambigüedad entre el aparecer(se) y el ocultar(se), y que por cierto, se expresa en "las representaciones de la Gorgona más antiguas que son máscaras con forma de olla de tamaño superior al natural, que eran ofrendas votivas a la Hera de Tirinto" (Burkert 266).

La imagen de la Gorgona es aterradora, traza el umbral ante el espanto de la muerte y más precisamente una muerte espantosa. La referencia a la Gorgona alude también a la ferocidad y hostilidad bélica con que los guerreros intimidan a sus enemigos, que mediante sus gritos de guerra, en el preludio de la batalla, es su primer mensaje de muerte a sus oponentes (Homero 740-745). Aquella imagen grotesca de la boca abierta del monstruo, "abierta de par en par, evoca el grito de guerra que Aquiles, resplandeciente bajo la llama que Atenea hace brotar de su cabeza, que profiere tres veces antes de lanzarse a la batalla [...] hace estremecer de terror las filas enemigas" (Vernant, La muerte en los ojos 56).

Estas tres bellas imágenes, entre tantas innúmeras, básicamente notifican la centralidad consustancial de la figura de lo Otro, de lo inhóspito, lo ominoso e inquietante, en su relación de coimplicancia y beligerancia constitutiva de la comunidad. Imágenes cuya figuración trágica — parafraseando a Didi-Huberman—, exigen de nosotros un trabajo de "arqueología", pues en ellas el pasado se nos torna intensamente presente en un destello, para eclipsar al instante siguiente (Didi-Huberman, Imágenes 79). Estas imágenes son también portadoras y promotoras de una economía ocular de la figuración, de una sensualidad óptico-política, donde el lenguaje y la escucha, ${ }^{2}$ tanto su posibilidad como su privación, traman la disputa eterna por el reconocimiento de lo Otro en lo-común.

Estas “imágenes-públicas" son las que han constituido la historia de la ciudad y de "lo público"; son el antecedente precoz de una concepción de la ciudad y de "lo político", como la inscripción y registro de una mundanidad escénica colmada de fuerzas y cuerpos múltiples, diversos, plurales, litigiosos. Allí, el espacio geométrico de la ciudad trama el paisaje cívico-político que revela y oculta un juego de inteligibilidad e ininteligibilidad, reconocimiento y negación. Esta "imagen-pública” traza y performa el decorado público-político, siempre incierto y hostil, en el que los mortales agencian su vida en común, bajo el signo siempre cruento e incierto del acontecimiento de la mirada.

2 Si bien en el presente artículo hemos centrado la atención en la dimensión visual del nacimiento de lo público-político, hemos omitido la dimensión sensible de la escucha. Una amplia y riquísima literatura tanto clásica como moderna se ha referido a esta crucial dimensión. El examen, registro y diálogo con dicha tradición lo hemos ensayado en trabajos anteriores. En lo inmediato referenciamos: Arancibia Carrizo, Juan Pablo. "Comunidad, música, poesía". Mapocho Revista de Humanidades, segundo semestre 2012, pp. 27-50; Arancibia Carrizo, Juan Pablo. "De la comunidad política a la comunidad musical. Politicidad de la música-musicalidad de la política”. Revista Textos y Contextos, n. ${ }^{\circ} 17$, 2017, pp. 37-70; Arancibia Carrizo, Juan Pablo. "Acusmática, de lo inquietante y lo ruinoso: hacia una estética de lo siniestro". La experiencia musical acusmática, Ed. F. Schumacher. Santiago, Ed. Pueblo Nuevo, 2019, pp. 29-46. 


\section{Referencias}

Adrados, R., Fernández-Galiano, Luis Gil y Lasso de la Vega. Introducción a Homero. Madrid, Guadarrama, 1963.

Agamben, Giorgio. Lo que queda de Auschwitz. El archivo y el testigo. Homo Sacer III. Valencia, Pre-textos, 2000.

- - Ninfas. Valencia, Pre-textos, 2010.

Amado, Adriana, editora. La comunicación pública como espectáculo. Relatos de la Argentina del siglo XXI. Buenos Aires, Konrad Adenauer, 2015.

Andrade, Gabriela y María Luisa Vial. Los mitos de los dioses griegos. Santiago, Editorial Andrés Bello, 2002.

Arancibia, Juan Pablo. Comunicación política. Fragmentos para una genealogía de la mediatización en Chile. Santiago, Editorial Universidad Arcis, 2006.

Arendt, Hannah. La condición humana. Barcelona, Paidós, 1993.

Aristóteles. Metafísica. Madrid, Gredos, 1994.

-—. Física. Madrid, Gredos, 1995.

——. Poética. Edición trilingüe. Madrid, Gredos, 1999.

-_. Política. Madrid, Gredos, 1999.

Aspe, Virginia. El concepto de técnica, arte y producción en la filosofía de Aristóteles. México, Fondo de Cultura Económica, 1993.

Barnes, Jonathan. Los presocráticos. Madrid, Ediciones Cátedra, 1992.

Baudrillard, Jean. Crítica de la economía política del signo. México, Siglo xxi, 1997.

Benjamin, Walter. La obra de arte en la época de su reproductibilidad técnica. Buenos Aires, Taurus, 1989.

Bermejo Barrera, José Carlos. "Mito y filosofía”. Historia de la filosofía antigua, Ed.

Carlos García Gual. Madrid, Trotta, 2004, pp. 21-43.

Bernabé, Alberto. Textos Órficos y Filosofía Presocrática. Materiales para una comparación. Madrid, Trotta, 2004.

Bernal, Martin. Atenea Negra. Las raíces afroasiáticas de la civilización clásica. Volumen I. Barcelona, Grijalbo-Mondadori, 1993.

Bonnefoy, Yves. Lugares y destinos de la imagen. Un curso de poética en el Collège de France (1981-1993). Buenos Aires, El Cuenco de Plata, 2007.

Bowra, C. M. Historia de la literatura griega. México, Fondo de Cultura Económica, 1948.

- - La aventura griega. Madrid, Guadarrama, 1960.

Bozal, Valeriano. Mímesis: las imágenes y las cosas. Madrid, Antonio Machado Ediciones, 1987.

Burckhardt, Jacob. Historia de la cultura griega. Barcelona, Iberia, 1964.

Burkert, Walter. Homo necans. Interpretaciones de ritos sacrificiales y mitos de la antigua Grecia. Barcelona, Acantilado, 2013. 
Cassin, Barbara. Vocabulaire européen des philosophies. Dictionnaire des intraduisibles. París, Le Robert-Seuil, 2004.

-_. El efecto sofístico. Buenos Aires, Fondo de Cultura Económica, 2008.

Castoriadis, Cornelius. Lo que hace a Grecia. De Homero a Heráclito. Buenos Aires, Fondo de Cultura Económica, 2006.

Cohen, Robert. Atenas, una democracia. Barcelona, Aymá, 1961.

Cornavaca, Ramón. Presocráticos. Fragmento I. Barcelona, Losada, 2008.

Cornford, F. M. Principium sapientiae. Madrid, La Balsa de la Medusa, 1987.

- - Platón y Parménides. Madrid, La Balsa de la Medusa, 1989.

Dayan, Daniel. “Televisión de intervención y espectáculo político. Obrar mediante el rito". Comunicación y política, Ed. Gilles Gauthier. Barcelona, Gedisa, 1998, pp. 175-202.

Debord, Guy. La sociedad del espectáculo. Santiago, Naufragio, 1995.

Debray, Régis. Vida y muerte de la imagen. Historia de la mirada en Occidente. Barcelona, Paidós, 1998.

Demóstenes. Discursos ante la Asamblea. Madrid, Akal, 2008.

De Romilly, Jacqueline. La tragedia griega. Madrid, Gredos, 2011.

Detienne, Marcel. Les maîtres de vérité dans la Grèce archaïque. París, Le Livre de Poche, 2006.

Didi-Huberman, Georges. Imágenes pese a todo. Memoria visual del Holocausto. Barcelona, Paidós, 2004.

- - Ante el tiempo. Historia del arte y anacronismo de las imágenes. Buenos Aires, Adriana Hidalgo, 2011.

- - . "La emoción no dice 'yo'. Diez fragmentos sobre la libertad estética”. La política de las imágenes. Santiago, Metales Pesados, 2017, pp. 39-67.

Elizalde, Luciano. Gestión de la comunicación pública. Empresas, grupos e instituciones en el escenario público. Barcelona, Bosch, 2009.

Escobar, Ticio. Imagen e intemperie. Las tribulaciones del arte en los tiempos del mercado total. Madrid, Clave Intelectual, 2015.

Esquilo. Las coéforas. Obras Completas. Madrid, Ediciones Cátedra, 2012.

Eurípides. Las Bacantes. Obras Completas. Madrid, Ediciones Cátedra, 2012.

- - Ión. Obras Completas. Madrid, Ediciones Cátedra, 2012.

Ferraté, Juan. Líricos griegos arcaicos. Antología. Barcelona, Seix Barral, 1968.

Finley, Moses. El nacimiento de la política. Barcelona, Crítica, 1986.

Forrest, W. G. La democracia griega. Trayectoria política del 800 al 400 a. de J. C. Madrid, Guadarrama, 1966.

Foucault, Michel. El gobierno de sí y de los otros. Buenos Aires, Fondo de Cultura Económica, 2009.

- - Lecciones sobre la voluntad de saber. Buenos Aires, Fondo de Cultura Económica, 2012. 
Francotte, Henri. La polis grecque. Recherches sur la formation et l'organisation des cités, des ligues et des confédéretions dans la Grèce Ancienne. Paderborn, Druck und Verlag von Ferdinand Schöningh, 1907.

Gallego, Julián. La democracia en tiempos de tragedia. Asamblea ateniense y subjetividad política. Buenos Aires, Editorial Miño y Dávila y Universidad de Buenos Aires, 2003.

-—. "El héroe trágico, el ondulante mar y la insularidad". Dialogues d'histoire ancienne, vol. 40, n. $^{\circ} 2,2014$, pp. 137-154.

- - " "La asamblea, el teatro y el pensamiento atenienses". Nova Tellvs, vol. 34, no 1 , 2016, pp. 13-54.

García, Luis. "La comunidad en montaje: Georges Didi-Huberman y la política en las imágenes”. Aisthesis, n 61, 2017, pp. 93-117.

Gernet, Louis. Droit et institutions en Grèce Antique. París, Flammarion, 1982.

-_. Anthropologie de la Grèce Antique. París, Flammarion, 2002.

Gil Fernández, Luis. Sobre la democracia ateniense. Madrid, Dykinson, 2009.

- - . "El individuo y su marco social". Introducción a Homero. Eds. R. Adrados, Fernández-Galiano, Luis Gil y Lasso de la Vega. Madrid, Ediciones Guadarrama, 1963, pp. 359-463.

Gilgamesh, o la angustia de la muerte. Poema babilonio. Barcelona, Kairós, 2010.

Glotz, Gustave. La cité grecque. París, La Renaissance du Livre, 1928.

Gordoa, Víctor. El poder de la imagen pública. Plan maestro para inspirar confianza y ganar credibilidad. México, Paperback, 2007.

Graves, Robert. Los mitos griegos. Buenos Aires, Alianza Editorial, 2012.

Gruzinski, Serge. La guerra de las imágenes. De Cristóbal Colón a "Blade Runner" (1492-2019). México, Fondo de Cultura Económica, 2006.

Habermas, Jürgen. Historia y crítica de la opinión pública. La transformación estructural de la vida pública. Barcelona, Gustavo Gili, 1994.

Heidegger, Martin. "La doctrina platónica de la verdad”. Hitos. Madrid, Alianza Editorial, 2000, pp. 173-198

-_. Parménides. Madrid, Akal, 2005.

Heródoto. Historia. Barcelona, Gredos, 2000.

Herreras, Enrique. La tragedia griega y los mitos democráticos. Madrid, Editorial Biblioteca Nueva, 2010.

Hesíodo. Obras y Fragmentos. Teogonía. Trabajos y Días. Escudo. Fragmentos. Certamen. Barcelona, Gredos, 2000.

Homero. Ilíada. Madrid, Abada, 2012.

Iriarte, Ana. Democracia y Tragedia: la era de Pericles. Madrid, Akal, 1996.

Jaeger, Werner. Paideia: los ideales de la cultura griega. México, Fondo de Cultura Económica, 2001.

Jay, Martin. Ojos Abatidos: la denigración de la visión en el pensamiento francés del siglo XX. Madrid, Akal, 2007. 
Jiménez, José. La imagen surrealista. Madrid, Trotta. Madrid, 2013.

Kay, Ronald. Del espacio de acá. Señales para una mirada americana. Santiago, Ediciones Nómade, 1980.

Kirk, G. S. La naturaleza de los mitos griegos. Barcelona, Labor, 1992.

Lesky, Albin. La Tragedia Griega. Barcelona, Acantilado, 2001.

- - Historia de la literatura griega. De los comienzos a las polis griega. Madrid, Gredos, 2009.

Loraux, Nicole. La ciudad dividida. El olvido en la memoria de Atenas. Madrid, Katz, 2004.

- - Mito y política en Atenas. Nacido de la tierra. Buenos Aires, El Cuenco de Plata, 2007.

- - La guerra civil en Atenas. La política entre la sombra y la utopía. Madrid, Akal, 2008.

Mossé, Claude. Historia de una democracia: Atenas. Madrid, Akal, 2016.

Moxey, Keith. El tiempo de lo visual. La imagen en la historia. Barcelona, Sans Soleil, 2015.

Murray, Gilbert. Historia de la literatura clásica griega. Buenos Aires, Albatros, 1947. Ossa, Carlos. El ojo mecánico. Cine político y comunidad en América Latina. Santiago, Fondo de Cultura Económica, 2013.

-_. "El soberano óptico: la formación visual del poder". Revista Chilena de Literatura, n. ${ }^{\circ}$ 89, 2015, pp. 213-230.

- - "La metamorfosis del príncipe". Chasqui. Revista Latinoamericana de Comunicación, n. ${ }^{\circ}$ 136, diciembre 2017-marzo 2018, pp. 215-229.

Ossandón, Carlos. La sociedad de los artistas. Santiago, Palinodia-Dibam, 2007.

Platón. Fedro. Diálogos III. Madrid, Gredos, 1992.

- - Filebo. Diálogos VI. Madrid, Gredos, 1992.

- - Timeo. Diálogos VI. Madrid, Gredos, 1992.

-—. Fedón. Diálogos III. Madrid, Gredos, 1997.

- - República. Edición griego-español. Madrid, Centro de Estudios Políticos y Constitucionales, 1997.

- - República. Diálogos IV. Madrid, Gredos, 1998.

-_. Parménides. Diálogos Libro v. Madrid, Gredos, 2002.

Plácido, Domingo. "La ciudad griega como marco y consecuencia de la conflictividad social". Revista Vínculos de Historia, n. ${ }^{\circ}$ 3, 2014, pp. 14-33.

Plutarco. Vidas Paralelas. Buenos Aires, El Ateneo, 1952.

Protágoras. Protágoras. Fragmentos y testimonios. Barcelona, Orbis, 1980.

Rancière, Jacques. Sobre políticas estéticas. Barcelona, Universidad Autónoma de Barcelona, 2005.

Sarti, Susanna. Arte griego. Enciclopedia visual del arte. Florencia, Scala, 2010.

Schmitt, Carl. El nomos de la tierra. En el derecho de gentes del "Jus publicum europaeum”. Buenos Aires, Struthart, 2005. 
Sennett, Richard. El declive del hombre público. Un sugestivo ensayo sobre la crisis actual en la vida urbana y cómo la "sociedad íntima" ha privado al hombre de su espacio público. Barcelona, Península, 2002.

- - Carne y Piedra. El cuerpo y la ciudad en la civilización occidental. Madrid, Alianza Editorial, 2010.

Tornos, Joaquín y Alfredo Galán, coordinadores. Comunicación pública. La información administrativa al ciudadano. Barcelona, Ediciones Jurídicas y Sociales, 2000.

Tucídides. Historia de la guerra del Peloponeso. Barcelona, Gredos, 2000.

Verón, Eliseo. El cuerpo de las imágenes. Bogotá, Norma, 2001.

Vernant, Jean-Pierre. La muerte en los ojos. Figuras del Otro en la antigua Grecia. Barcelona, Gedisa, 2001.

- - Los orígenes del pensamiento griego. Barcelona, Paidós, 2004.

- - Érase una vez... El universo, los dioses, los hombres. Buenos Aires, Fondo de Cultura Económica, 2005.

-- Mito y pensamiento en la Grecia Antigua. Barcelona, Ariel, 2007.

- - Atravesar fronteras. Entre mito y política II. Buenos Aires, Fondo de Cultura Económica, 2008.

Vidal-Naquet, Pierre. El espejo roto. Tragedia y política en Atenas en la Grecia Antigua. Madrid, Abada, 2004.

-_. El mundo de Homero. Buenos Aires, Fondo de Cultura Económica, 2007.

Virilio, Paul. Cibermundo. ¿una política suicida? Santiago, Dolmen, 1997.

Weil, Simone. La fuente griega. Madrid, Trotta, 2005.

Wilcken, Ulrich. Historia de Grecia. Madrid, Pegaso, 1959.

Zeitlin, Froma. "The artful eye: vision, ecphrasis and spectacle in Euripidean theatre". Art and text in ancient Greek culture, Cambridge, Ed. Simon Goldhill y Robin Osborne. Cambridge University Press, 1994. pp. 138-196.

Enviado: 29 de octubre de 2018 Aceptado: 7 de septiembre de 2020 